point may have been the obstruction. At that time the water, filled with floating ice, may have made the striæ as it flowed over the top of this dam; - until finally it cut a chasm through the obstruction.

Another fact suggesting the same probability is that from this anticline for many miles up the river there are considerable Loess deposits. These may have been made before the obstruction was was cut through.

But while the striæ at this place might be thus accounted for, this would gire no sufficient explanation of the presence of the bowlders. etc., scattered over these hills many miles from the river and several hundred feet above its bed. In fact there are now three or four feet of clay or soil overlaying the very rocks which have the supposed glacial scratches on them, and this clay, etc, has in it pebbles and small bowlders of the same kind as those scattered orer the surface of this section.

So, upon the whole, I think bowlders, striæ, and all are of true glacial origin.

Fayette, Mo.. Dec. 9.

J. W. KIRKPATRICK.

\section{Mexican Featherwork.}

"THE most famous surviving specimen is the standard, described by Hochstetter, which is now in the Vienna Ethnographical Museum " (Science. Dec. 4, p. 311, 2d col., top). This splendid piece of old Mexican featherwork is the subject of special publications by Mrs. Julia Nuttall, entitled "Das Prachtstück altmexicanischer Federarbeit aus der Zeit Montezuma's im Wiener Museum " (Reports of the Dresden Museum, 1887), and "Standard or Headdress" (Archæol. and Ethnol. Papers, Peabody Mus., Harrard, 1888 , Vol. I., No. 1). Both these papers are elaborately illustrated and bring forward overwhelming evidence to show that what has hitherto been considered an Aztec standard is really a head decoration.

\section{Kansas Mosasaurs.}

HITHERTo, no adequate description or figure has ever been published of the complete anatomy, or even of the skull, of any mem. ber of the extinct group of reptiles known as the Mosasaurs or Pythonomorpha. Fortunately, however, my able friend Dr. Baur has recently had the opportunity to thoroughly study an excellent specimen of one of the Kansas forms, and his figures and descriptions, when published, will doubtless be of great interest. The University of Kansas has, within recent years, obtained one of the most valuable collections of these animals now extant. Among this material, there is one specimen of especial interest, by reason of its remarkable completeness, consisting, as it does, of skull and connected vertebræ to the tip of the tail, with ribs, extremities, and cartilages in position.

Before briefly describing this specimen, which belongs to a different genus from that studied by Dr. Baur, I may be permitted to offer the following remarks upon the nomenclature of the Kansas forms, based upon larger opportunities than have been enjoyed, I believe, by any otber incestigator.

The following generic names have been proposed or adopted by various writers for the different forms of these reptiles from the Kansas Cretaceous: Liodon Owen, Platecarpus Cope, Clidastes Cope, Sironectes cope, Lestosaurus Marsh, Tylosaurus Narsh, Edestosaurus Marsh, and Holosaurus Marsh. Three genera, only, can be readily and positively distinguished among the material. The names now recognized for these, and with justice, are: Liodon, Platecarpus, and Clidastes. Two others, Sironectes and Holosaurus, have, possibly some claims for recognition, but the evidence in favor of either is, so far, very weak. Holosaurus is not synonymous with Sironectes, as affirmed by Cope and followed by Dullo. Holosaurus rests almost solely upon a single cbaracter, the non emarginate coracoid; in other respects nothing is known to separate it from Platecarpus. In fact, Platecarpus itself may possess this very character. That the character was not considered by the author of Holosaurus as important is evidenced by the following. In the American Journal of Science (Vol. iii., June, 1872, p. 5 of separate) he says: "There is certainly no emargination in the coracoid of Clidastes, Edestosaurus, and Baptosaurus, as specimens in the Yale Museum conclusively prove." A tigure of the coracoid of Clidastes (Edestosaurus) dispar, given in the same paper, shows the bone entire. In the same paper in which Holosaurus is figured and described (Amer. Jour. Sci., vol. xix., pp. 83-87) a restoration is given of the shoulder girdle of "Edestosaurus dispar Marsh," in which the coracoid is very conspicuously seen to be emarginate. That this was not an error on the part of the artist, I can vouch, for the specimen from which the figure was made was collected and restored by myself. There is a lack of consistency here somewhere.

A fuller discussion of the genera and generic characters of the Kansas material,I leave to a future occasion. As there have been more than twice too many generic names given; so, too, it is pretty evident that there is even a greater proportion of synonyms among the specific names. The specific nomenclature is, at present, however, a subject of great intricacy, of which no one is master. Mr. E. C. Case of the State University will shortly publish a paper on this subject.

With these general observations, I will now give a brief description of the specimen above mentioned; a fuller description, with illustrations, will appear later. The specimen is a Clidastes (Edestosaurus) and, from Mr. Case's studies, probably C. velox Marsh, which is apparently the same as the earlier described $c$. cineriarum Cope. The specimen measures, from the tip of the tail to the tip of the rostrum, one hundred and thirty-nine and onehalf inches, including altogether one hundred and seventeen vertebræ, the whole regionally divided as follows: skull, seventeen and one-half inches: cervical region, seven vertebræ, eight and one-half inches; costifarous, post-cervical region, thirty-four vertebræe, fifty-four and one-half inches; non-rib or chevron-bearing region, seven vertebræ, eight and one half inches; chevron bearing region, sixty-eight vertebræ, fifty-one and one half inches. All of the cerrical vertebræ, save the atlas, have ribs, those of the axis, though, are very small, increasing in the last cervical to about three inches in length. The first to the ninth dorsal, or true thoracic, ribs, those articulating with the cartilaginous sternum through the intercention of cartilaginous ribs, are of ntarly equal length, about eight and one-half inches, and are moderately curved. The eleventh dorsal rib is but four inches long, and thence to the thirty-fifth or last, they decrease gradually to about two inches. The rib-bearing processes, as well as the vertebræ themselres, do not differ much throughout the series. The longest costal cartilage preserved does not measure over four inches; this will give, with the sternum and vertebræ, a total circumference of the thorax not. exceeding thirty inches.

Immediately following the last costiferous vertebra, are seven vertebræw with elongate transverse processes, and without chevrons. From the position of the pelvis, it was evidently attached to the first of these vertebræ, none of which can be properly called lumbar. With the first chevron-bcaring vertebra, the transverse processes begin to decrease in length, and finally disappear in the twenty-fifth or twenty-sixth.

The tail is elongate, slender, and compressed, the spines and cherrons having their greatest length only about one foot from the extremity, where the tail measures nearly six inches in height.

Of the paddles little need be said. The hind pair was decidedly smaller and less strong than the fore pair, the latter having an outstretched expanse of about thirty inches.

As a whole, this, one of the most specialized species of the most specialized genus of known extinct or recent lizards, was most marvellously serpentine and slender in its build, with an elongate, flattened, pointed head, short neck, very slender body, long, lithe, and vertically flattened tail, small but broad and strong paddlelike limbs. It is doubtful whether there was ever another vertebrated animal so admirably adapted for rapid and varied movements through the water. Though the smallest of the Mosasaurs, it was by far the most graceful in its proportions, the most delicateand exquisitely constructed in its details.

It is certain that none of the Kansas forms of this order were covered with bony scutes, as described by Marsh, the bones so described being, undoubtedly, sclerotic plates.

University of Kansas, Dec. 1.
S. W. WILliston。 